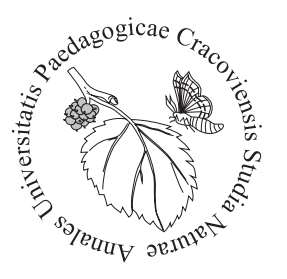

Gracjana Budzałek, Sylwia Śliwińska-Wilczewska*, Adam Latała Institute of Oceanography, University of Gdansk, Gdynia, Poland, *s.sliwinska@ug.edu.pl

\title{
Allelopathic effect of Ulva intestinalis L. on the Baltic filamentous cyanobacterium Nostoc sp.
}

\section{Introduction}

Field evidence and laboratory studies indicate that allelopathy occurs in all aquatic habitats (marine, brackish, and freshwater) and that all primary producing organisms (cyanobacteria, micro- and macroalgae as well as angiosperms) are capable of producing and releasing allelopathically active compounds (Tang, 2011). Molisch (1937) was the first who defined the term allelopathy in a broad sense to describe either positive or negative biochemical interactions among plants. After a few decades, Inderjit and Dakshini (1995) gave an overview of allelopathic activities in aquatic habitats with particular emphasis on algae. Currently, it is believed that allelopathy is a prevalent natural phenomenon in aquatic ecosystem (Omezzine et al., 2009).

Macroalgae from the genus Ulva are cosmopolitan organisms, and in nutrient-rich coastal waters, they are often dominant and even bloom-forming species (Rybak, 2018a,b; Rybak, Gąbka, 2018). Several species of Ulva have distributions that extend into the Baltic Sea (Leskinen, 2004). Ulva intestinalis L. (synonym: Enteromorpha intestinalis (L.) Nees) is the principal marine and benthic macroalga growing in isolated rockpools, on rocks, and even on artificial substrates (breakwaters, jettys, etc.) (Björk, 2004). Some researchers have demonstrated that Ulva can reduce eutrophication and promote the productivity, survival rate, and feeding coefficient of the culture species, e.g., prawn and shrimp, by means of polyculture (Wang et al., 2001). Many papers have reported that Ulva can take up nutrients from mariculture waters and improve water quality (Jin, Dong, 2003).

Harmful cyanobacterial blooms (CyanoHABs) are a significant threat to fisheries, economies around the world, and public health (Paerl, 2018). On the other hand, allelopathy in aquatic environments may provide a competitive advantage of selected macroalgae relative to other primary producers, including cyanobacteria (Gross, 2010). 
Thus, allelopathic macroalgae may be a promising mitigation strategy for CyanoHABs (Tang, 2011). However, we have still little knowledge about the allelopathic interactions between the macroalgae and cyanobacteria. In the present study, we performed a series of laboratory experiments under controlled conditions to examine the allelopathic interactions between the Ulva intestinalis and Nostoc sp. in order to verify the hypothesis of allelopathy between macroalgae and cyanobacteria.

\section{Material and methods}

The experiments were conducted with the strain BA-81 of cyanobacterium Nostoc sp. (Fig. 1). This strain was isolated from the coastal zone of the Gulf of Gdańsk (southern Baltic Sea) and was maintained as monocultures in the Culture Collection of Baltic Algae (CCBA) at the Institute of Oceanography, the University of Gdańsk, Poland (Latała et al., 2006). Brackish water adapted macroalgae U. intestinalis was selected, based on allelopathic potential of species from the order Ulvales (e.g., Nan et al., 2004). Analysed green alga was collected manually from the coastal zone of the Gulf of Gdańsk $\left(54^{\circ} 30^{\prime} 16^{\prime \prime} \mathrm{N} 18^{\circ} 33^{\prime} 26^{\prime} \mathrm{E}\right)$ and immediately and carefully washed with distilled water to remove attached organisms.

The cyanobacteria culture used in the experiments was maintained in $25-\mathrm{mL}$ glass Erlenmeyer flasks at $17^{\circ} \mathrm{C}$ and a $16: 8 \mathrm{~h}$ of light : dark cycle at a irradiance of $20 \mu \mathrm{mol}$ photons (PAR) $\mathrm{m}^{-2} \mathrm{~s}^{-1}$. The culture was acclimated to these conditions for 7 days, and these growth conditions were used for the experiments. Fluorescent lamps (Cool White 40W, Sylvania, USA) were used as a source of irradiance. The intensity of Photosynthetically Active Radiation (PAR) was measured using a quantum-meter (LICOR, Nebraska, USA) with a cosine collector. The culture medium employed was $\mathrm{f} / 2$ (Guillard, 1975). Culture media were prepared with Baltic Sea water filtered through

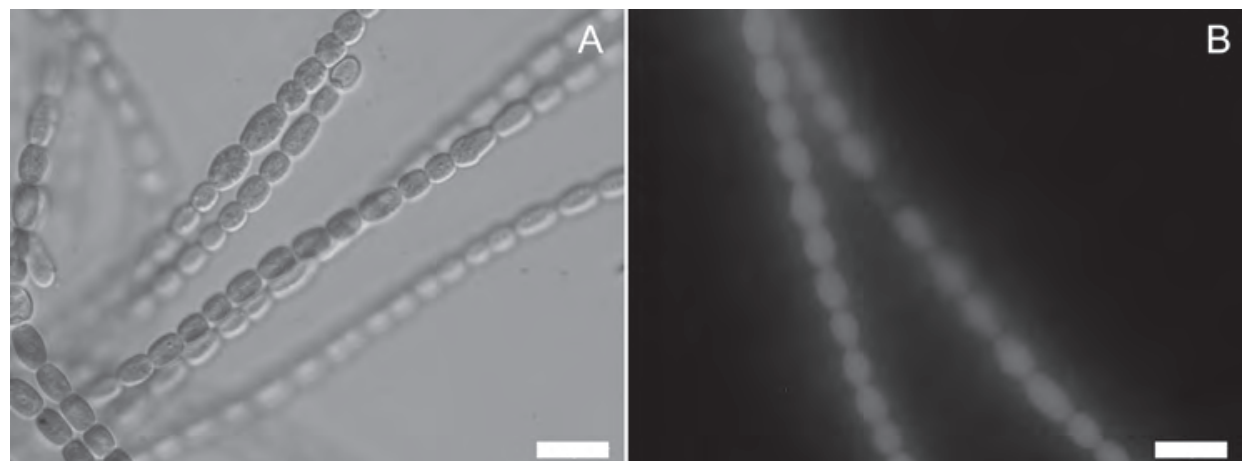

Fig. 1. Nostoc sp. strain BA-81 used in this study: left panel depicts cyanobacterial filaments from the light microscope (A), whilst right panel illustrates target species under an epifluorescence microscope (B). Scale bars $=10 \mu \mathrm{m}$ (Photo. S. Śliwińska-Wilczewska) 
glass fibre filters (Whatman GF/C) and autoclaved. The salinity was 8 PSU as measured with a salinometer (inoLab Cond Level 1, Weilheim in Oberbayern, Germany).

Allelopathic effects were tested according to a method proposed by Ghobrial et al. (2015) with modifications. The cyanobacteria cultures were exposed to the macrophyte extracts obtained from U. intestinalis. Dried plant materials were homogenised in a mortar grinding machine. For the bioassay experiment, $2 \mathrm{~g}$ dry weight of dried plants was extracted with $40 \mathrm{~mL}$ of $\mathrm{f} / 2$ medium for 10 minutes. Extracts were filtered through glass fibre filters (Whatman GF/C) using a vacuum pump (400 mbar) to remove plant particles for bioassay experiments. The concentrations of major nutrients in the controls and all treatments were adjusted to the same level as in the $f / 2$ growth medium. Therefore, the effects of major nutrients, microelements, and vitamin limitations in the control and allelochemical treatments can be excluded.

Sterilised Erlenmeyer flasks $25-\mathrm{mL}$ contained $10 \mathrm{~mL}$ f/2 medium with a cyanobacterial initial inocula (the final chlorophyll $a(\mathrm{Chl} a)$ concentration in the experimental cultures was $0.4 \mu \mathrm{g} \mathrm{Chl} a \mathrm{~mL}^{-1}$ ) and different volumes of green alga extract treatments. Experimental treatments were prepared by adding 100,500, and $1000 \mu \mathrm{L}$ of these extracts to $25-\mathrm{mL}$ Erlenmeyer flasks containing $10 \mathrm{~mL}$ of cell suspensions of the targeted cyanobacteria. The final concentrations of extract were 10,50 , and $100 \mu \mathrm{L} \mathrm{mL}^{-1}$. The selection of these concentrations was based on previous introductory experiments to determine the effective-range broadly. Controls consisted in the addition of 100, 500, and $1000 \mu \mathrm{L}$ of filtrated f/2 medium to $25-\mathrm{mL}$ Erlenmeyer flasks containing $10 \mathrm{~mL}$ of cell suspensions of the same cyanobacteria species. The aliquots of the target species inoculated in the experimental flasks came from exponentially growing cultures. The flasks with cyanobacteria were swirled daily. Tests were conducted in triplicate. The experiments lasted 7 days.

The number of cells (N) in Nostoc sp. cultures was estimated with previously determined linear correlations between cell abundance $\left(\mathrm{N} \mathrm{mL}^{-1}\right)$ and optical density (OD). $\mathrm{N}$ was counted using a Bürker chamber (48 squares per count) and a light microscope (LM) following a procedure according to Guillard and Sieracki (2005), and the OD was measured spectrophotometrically at $750 \mathrm{~nm}$ with a Multiskan GO UV-VIS spectrophotometer (Thermo Scientific, Massachusetts, USA). The linear correlation between $\mathrm{N}$ and OD for Nostoc sp. was $\mathrm{y}=39.8 \cdot 10^{6} \mathrm{x}-1.1 \cdot 10^{4} ;\left(r^{2}=0.95\right)$, where $\mathrm{y}=\mathrm{N}$ $\left(\mathrm{mL}^{-1}\right)$ and $\mathrm{x}=\mathrm{OD}$. OD measurements were performed on the $0^{\text {th }}, 1^{\text {st }}, 3^{\text {rd }}$, and $7^{\text {th }}$ days of experiment and control.

Chlorophyll $a$ fluorescence was measured with a Pulse Amplitude Modulation (PAM) fluorometer (FMS1, Hansatech), using a $594 \mathrm{~nm}$ amber modulating beam with a 4-step frequency control as a measuring light. Samples were taken for chlorophyll fluorescence analysis after the $1^{\text {st }}, 3^{\text {rd }}$, and $7^{\text {th }}$ days of experiment. Samples were filtered through 13-mm glass fibre filters (Whatman GF/C). Before measurement, the filtered 


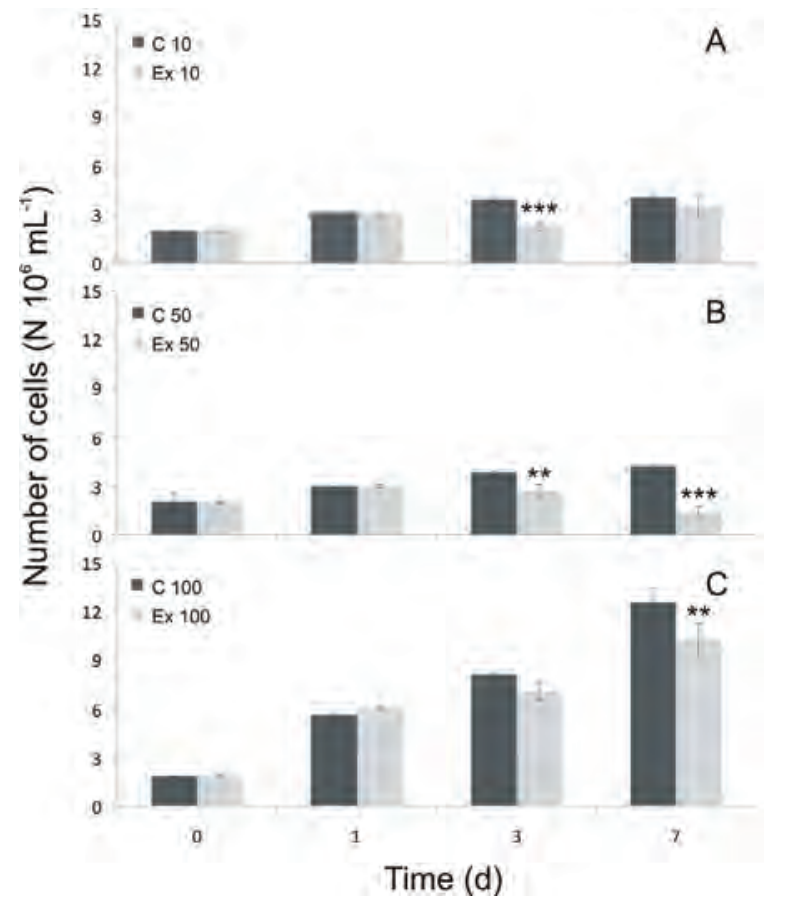

Fig. 2. The number of Nostoc sp. cells $\left(10^{6}\right.$ cell $\left.\mathrm{mL}^{-1}\right)$ for controls (C) and experiments (Ex) with addition of extracts: 10, 50 and $100\left(\mu \mathrm{L} \mathrm{mL}^{-1}\right)$ obtained from Ulva intestinalis $\mathrm{L}$. after $0,1,3$, and 7 days of exposure; the values refer to means $(n=3$, mean $\pm S D)$; asterisks indicates statistically significant difference compared with control obtained with the ANOVA and Tukey's post hoc test; levels of significance were: ${ }^{*} \mathrm{p}<0.05 ;{ }^{* *} \mathrm{p}<0.01 ;{ }^{* *} \mathrm{p}<0.001$

sample was kept in the dark for approximately $5 \mathrm{~min}$. The maximum PSII quantum efficiency $\left(\mathrm{F}_{\mathrm{v}} / \mathrm{F}_{\mathrm{m}}\right)$ was calculated (Campbell et al., 1998).

Repeated measures ANOVA was used to test the effect of macroalgae extract on the growth and fluorescence of the targeted cyanobacteria during the following days of experiment. A post-hoc Tukey's test was used to determine significant differences between the control and the other treatment levels. Data are reported as the means \pm standard deviations (SD). The statistical analyses were performed using Statistica 13.1 software.

\section{Results}

Our experiment demonstrated that the dry powder of $U$. intestinalis contains water-soluble allelochemical(s) and is capable of restricting the growth and fluorescence of filamentous cyanobacterium Nostoc sp. The addition of 10,50 , and $100 \mu \mathrm{L} \mathrm{mL}{ }^{-1}$ of extracts obtained from Ulva intestinalis significantly decreased the number of cells of Nostoc sp. (ANOVA, $F_{3,16}=11.2, \mathrm{p}<0.001$, ANOVA, $F_{3,16}=25.4, \mathrm{p}<0.001$ and ANOVA, $F_{3,16}=26.3, \mathrm{p}<0.001$, respectively), whereas the control sample showed ac- 
tive growth (Fig. 2). After the addition of extracts obtained from U. intestinalis, the highest decline in growth for Nostoc sp. was observed on the third and seventh day of the experiment. The growth of target cyanobacterium after the third day and the addition of 10 and $50 \mu \mathrm{L} \mathrm{mL}-1$ of extracts obtained from $U$. intestinalis was reduced to $59 \%$ (Tukey, $\mathrm{p}<0.001$ ) and $71 \%$ (Tukey, $\mathrm{p}<0.01$ ), respectively, compared to the control. Moreover, the addition of 50 and $100 \mu \mathrm{L} \mathrm{mL}^{-1}$ extracts inhibited the growth of cyanobacterium; and, after seven days of exposition, the reduction was 35\% (Tukey, $\mathrm{p}$ $<0.001$ ) and $81 \%$ (Tukey, $\mathrm{p}<0.01$ ), respectively, of the initial amount of Nostoc sp. The effect of macrophytes extracts on chlorophyll fluorescence parameter $F_{v} / F_{m}$ after 1,3 , and 7 days of incubation is shown in figure 3 . The cyanobacterium showed statistically significant different responses to 10,50 , and $100 \mu \mathrm{L} \mathrm{mL}^{-1}$ of extract additions obtained from $U$. intestinalis (ANOVA, $F_{2,12}=6.9, \mathrm{p}<0.001$, ANOVA, $F_{2,12}=0.9, \mathrm{p}>0.05$ and ANOVA, $F_{2,12}=44.5, \mathrm{p}<0.0001$, respectively). It was found that, on the third day of the experiment, the values of $\mathrm{F}_{\mathrm{v}} / \mathrm{F}_{\mathrm{m}}$ of target cyanobacterium after the addition of 10 $\mu \mathrm{L} \mathrm{mL} \mathrm{L}^{-1}$ extracts was reduced to $75 \%$ (Tukey, $\mathrm{p}<0.05$ ), compared to control treatment. The highest decrease in $\mathrm{F}_{\mathrm{v}} / F_{\mathrm{m}}$ for Nostoc sp. was observed after the first, third, and seventh day of experiment, after the addition of $100 \mu \mathrm{L} \mathrm{mL}^{-1}$ extracts obtained from $U$. inestinalis with a magnitude of $69 \%$ (Tukey, $\mathrm{p}<0.01$ ), 59\% (Tukey, $\mathrm{p}<0.001$ ) and $49 \%$ (Tukey, $\mathrm{p}<0.001$ ), respectively, compared to the control.

Discussion

Aquatic macroalgae and macrophytes have long been suspected of suppressing phytoplankton growth through the excretion of chemical substances that inhibit phytoplankton growth (Hutchinson, 1975). In addition, the production and excretion of allelochemicals by aquatic macroalgae and macrophytes could be an effective defence strategy against other photosynthetic organisms competing for nutrients and light (Wium-Andersen et al., 1982; Gopal, Goel, 1993; Elakovich, Wooten, 1995).

Some of the results confirmed that Ulva sp. is able to suppress the growth of different species by allelopathy (Friedlander et al., 1996). Nan et al. (2008) demonstrated that green macroalga Ulva sp. has allelopathic effects on the three species of red tide microalgae. Although toxic properties are rarely associated with the bloom-forming green macroalgae, there is evidence that Ulva sp. produce chemical defences against herbivores (Van Alstyne et al., 2001), and their extracts have allelopathic properties on other organisms, such as larval oyster, Fucus gardneri P.C. Silva zygote and epiphytic diatom (Nelson et al., 2002). On the other hand, Nan et al. (2004) demonstrated that in the nutrient replete semicontinuous co-cultures, Ulva sp. may have continuously released growth-inhibiting allelochemicals throughout the cultivation period; whereas, in the initial addition culture solution, the allelochemicals may inhibit growth only 


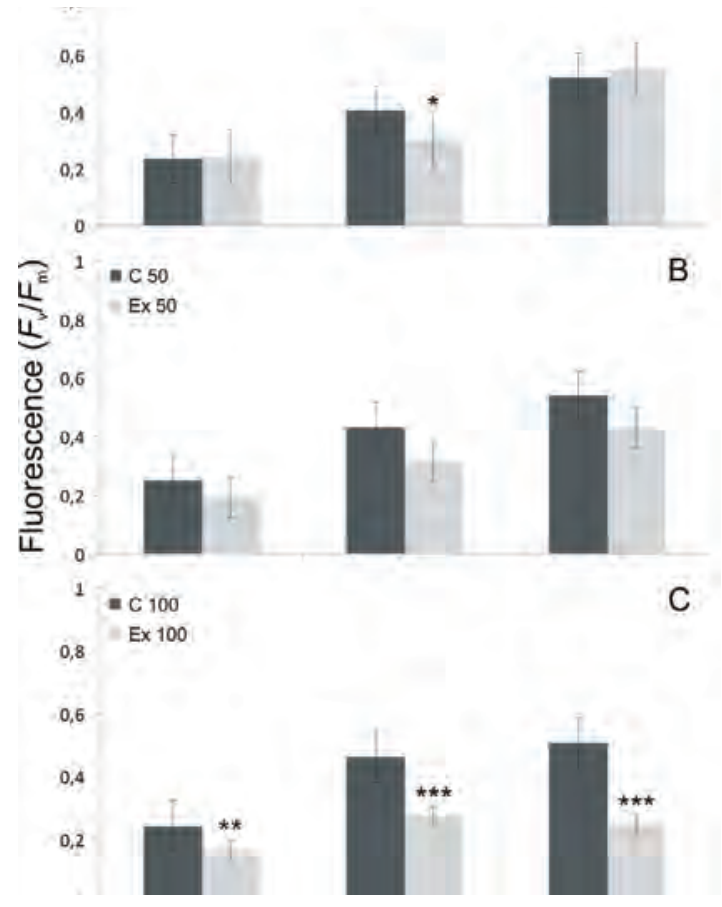

Fig. 3. The fluorescence parameter $F_{\mathrm{v}} / F_{\mathrm{m}}$ of Nostoc sp. cells for controls (C) and experiments (Ex) with addition of extracts: 10,50 and $100\left(\mu \mathrm{L} \mathrm{mL}^{-1}\right)$ obtained from Ulva intestinalis L. after 1,3 , and 7 days of exposure; the values refer to means $(n=3$, mean $\pm S D$ ); asterisks indicates statistically significant difference compared with control obtained with the ANOVA and Tukey's post hoc test; levels of significance were: ${ }^{*} \mathrm{p}<0.05$; $^{* *} \mathrm{p}<0.01{ }^{* * *} \mathrm{p}<0.001$

at the start of cultivation, because they are quickly degradable. Furthermore, Nakai et al. (1999) showed that initial addition culture solution might underestimate the allelopathic inhibitory effects as compared with coexistence assays. Moreover, allelochemicals could exhibit positive effects on the target organism at lower concentrations and exhibit negative effects at higher concentrations (Van Aller, 1985).

Other studies have shown that macrophytes may also exhibit allelopathic effects on different phytoplankton species, including cyanobacteria (Van Donk, Gulati, 1995; Mjelde, Faafeng, 1997). Mjelde and Faafeng (1997) found that Ceratophyllum demersum L. hampers phytoplankton development in some small Norwegian lakes over a wide range of phosphorus concentrations and geographical latitude. Moreover, Van Donk and Gulati (1995) suggested that C. demersum can inhibit the growth of both epiphytes and phytoplankton species. Additionally, the impact of different submerged macrophytes or their extracts on natural phytoplankton assemblages was studied under experimental conditions by Jasser (1995). This author also concluded that the release of organic compounds by $C$. demersum apparently contributed to a decline of cyanobacteria Oscillatoria limnetica Lemm. by changing the phytoplankton dominance 
structure. Natural phytoplankton assemblages, in which cyanobacteria were abundant, were incubated in the field in bags together with intact plants or plant extracts. Live C. demersum, Myriophyllum spicatum L., Potamogeton lucens L., Statiotes aloides L., and Chara fragilis Desv. and its extract, had quite similar effects on the phytoplankton; whereas, the biomass and percentage contribution of cyanobacteria to total algal biomass declined, and those of green algae increased. Wium-Andersen et al. (1983) isolated a sulphur compound with allelopathic properties from $C$. demersum. Moreover, Gross and Sütfeld (1994) found that M. spicatum L. was able to release allelopathic polyphenols into the surrounding water and thereby strongly suppressed the growth of cyanobacterium Anacystis sp. Some authors noted that the identified allelochemicals belong to different chemical classes, such as sulphur compounds, polyacetylenes, polyphenols, and oxygenated fatty acids; however, most of the allelochemicals are still not identified (Gross, 1999).

In this study, it has been demonstrated that $U$. intestinalis can release some kind of allelopathic substances and effectively inhibit the growth and fluorescence parameter of cyanobacterium Nostoc sp. Our results not only provide insight into the interactions between macroalgae and cyanobacteria but also lead us to isolate and characterize these allelopathic substances in the future. Moreover, our results may provide new insight into the ecological role of macroalgae, such as $U$. intestinalis, in the occurrence of CyanoHABs.

\section{Acknowledgements}

The authors would like to thank the anonymous reviewers for their valuable comments and suggestions to improve the quality of the paper. This study was supported by BMN grants, Poland, no. 538-G245-B116-18.

References

Björk, M., Axelsson, L., Beer, S. (2004). Why is Ulva intestinalis the only macroalga inhabiting isolated rockpools along the Swedish Atlantic coast? Marine Ecology Progress Series, 284, 109-116.

Campbell, D., Hurry, V., Clarke, A.K., Gustafsson, P., Öquist, G. (1998). Chlorophyll fluorescence analysis of cyanobacterial photosynthesis and acclimation. Microbiology and Molecular Biology Reviews, 62, 667-683.

Elakovich, S.D., Wooten, J.W. (1995). Allelopathic, herbaceous, vascular hydrophytes. In: Inderjit Dakshini, K.M.M., Einhellig, F.A. (eds.), Allelopathy: Organisms, Processes and Applications. Washington: American Chemical Society, 58. DOI: 10.1021/bk-1995-0582.ch004

Friedlander, M., Gonen, Y., Kashman, Y., Beer, S. (1996). Gracilaria conferta and its epiphytes: 3. Allelopathic inhibition of the red seaweed by Ulva cf. lactuca. Journal of Applied Phycology, 8, 21-25. DOI: $10.1007 / \mathrm{BF} 02186217$

Ghobrial, M.G., Nassr, H.S., Kamil, A.W. (2015). Bioactivity effect of two macrophyte extracts on growth performance of two bloom-forming cyanophytes. The Egyptian Journal of Aquatic Research, 41, 69-81. DOI: 10.1016/j.ejar.2015.01.001

Gopal, B., Goel, U. (1993). Competition and allelopathy in aquatic plant communities. Botany Research, 59, 155-210. DOI: 10.1007/BF02856599 
Gross, E.M. (1999). Allelopathy in benthic and littoral areas: case studies on allelochemicals from benthic cyanobacteria and submerged macrophytes. In: K.M.M. Inderjit Dakshini, C.L. Foy (eds.), Principles and Practices in Plant Ecology: Allelochemical Interactions. Boca Raton, FL: CRC Press.

Gross, E.M. (2010). Comments on increasing number and abundance of non-indigenous aquatic macrophyte species in Germany. Weed Research, 50, 519-526. DOI: 10.1111/j.1365-3180.2010.00812.x

Gross, E.M., Sütfeld, R. (1993). Polyphenols with algicidal activity in the submerged macrophyte Myriophyllum Spicatum L. International Symposium on Natural Phenols in Plant Resistance, 381, 710-716. DOI: 10.17660/ActaHortic.1994.381.103

Guillard, R.R.L. (1975). Culture of phytoplankton for feeding marine invertebrates. In: W.L. Smith, M.H. Chanley (eds.), Culture of Marine Invertebrate Animals. New York, USA: Plenum Press, 26-60. DOI: 10.1007/978-1-4615-8714-9_3

Guillard, R.R., Sieracki, M.S. (2005). Counting cells in cultures with the light microscope. Algal Culturing Techniques, 239-252.

Hutchinson, G.E. (1975). A Treatise on Limnology. Vol. 3. Limnological Botany. New York: Wiley.

Inderjit, Dakshini, K.M.M. (1995). On laboratory bioassays in allelopathy. Botanical Review, 61, 28-44. DOI: $10.1007 / \mathrm{BF} 02897150$

Jasser, I. (1995). The influence of macrophytes on a phytoplankton community in experimental conditions. Hydrobiologia, 306, 21-32. DOI: 10.1007/BF00007855

Jin, Q., Dong, S. (2003). Comparative studies on the allelopathic effects of two different strains of Ulva pertusa on Heterosigma akashiwo and Alexandrium tamarense. Journal of Experimental Marine Biology and Ecology, 293, 41-55. DOI: 10.1016/S0022-0981(03)00214-4

Latała, A., Jodłowska, S., Pniewski, F. (2006). Culture Collection of Baltic Algae (CCBA) and characteristic of some strains by factorial experiment approach. Algological Studies/Archiv für Hydrobiologie, 122, 137-154. DOI: $10.1127 / 1864-1318 / 2006 / 0122-0137$

Leskinen, E., Alstrom-Rapaport, C., Pamilo, P. (2004). Phylogeographical structure, distribution and genetic variation of the green algae Ulva intestinalis and U. compressa (Chlorophyta) in the Baltic Sea area. Molecular Ecology, 13, 2257-2265. DOI: 10.1111/j.1365-294X.2004.02219.x

Mjelde, M., Faafeng, B. (1997). Ceratophyllum demersum (L.) hampers phytoplankton development in some small Norwegian lakes over a wide range of phosphorus level and geographic latitude. Freshwater Biology, 37, 355-365. DOI: 10.1046/j.1365-2427.1997.00159.x

Molisch, H. (1937). Der einfluss einer pflanze auf die andere - Allelopathie. Jena: G. Fisher, Verlag, 106.

Nakai, S., Inoue, Y., Hosomi, M., Murakami, A. (1999). Growth inhibition of blue-green algae by allelopathic effects of macrophytes. Water Science and Technology, 39, 47-53. DOI: 10.2521/jswtb.33.215

Nan, C., Zhang, H., Zhao, G. (2004). Allelopathic interactions between the macroalga Ulva pertusa and eight microalgal species. Journal of Sea Research, 52, 259-268. DOI: 10.1016/j.seares.2004.04.001

Nan, C., Zhang, H., Lin, S., Zhao, G., Liu, X. (2008). Allelopathic effects of Ulva lactuca on selected species of harmful bloom-forming microalgae in laboratory cultures. Aquatic Botany, 89, 9-15. DOI: 10.1016/j.aquabot.2008.01.005

Nelson, T.A., Lee, D., Smith, B.C., Prins, R. (2002). Are 'green tides' harmful algal blooms? Allelopathic properties of extracts from Ulva fenestrata and Ulvaria obscura. Journal of Phycology, 38, 28-29. DOI: 10.1046/j.1529-8817.38.s1.82.x

Omezzine, F., Haouala, R., El Ayeb, A., Boughanmi, N. (2009). Allelopathic and antifungal potentialities of Padina pavonica (L.) extract. Journal of Plant Breeding and Crop Science, 1, 094-203.

Paerl, H.W. (2018). Mitigating Toxic Planktonic Cyanobacterial Blooms in Aquatic Ecosystems Facing Increasing Anthropogenic and Climatic Pressures. Toxins, 10, 76. DOI: 10.3390/toxins10020076 
Rybak, A.S. (2018a). Species of Ulva (Ulvophyceae, Chlorophyta) as indicators of salinity. Ecological indicators, 85, 253-261. DOI: 10.1016/j.ecolind.2017.10.061

Rybak, A.S. (2018b). The Ulva flexuosa complex (Ulvaceae, Chlorophyta): An updated identification key with special reference to the freshwater and hyperhaline taxa. Phytotaxa, 345(2), 83-103. DOI: 10.11646/phytotaxa.345.2.1

Rybak, A.S., Gąbka M. (2018). The influence of abiotic factors on the bloom-forming alga Ulva flexuosa (Ulvaceae, Chlorophyta): possibilities for the control of the green tides in freshwater ecosystems. Journal of Applied Phycology, 30(2), 1405-1416. DOI: 10.1007/s10811-017-1301-5

Tang, Y.Z., Gobler, C.J. (2011). The green macroalga, Ulva lactuca, inhibits the growth of seven common harmful algal bloom species via allelopathy. Harmful Algae, 10, 480-488. DOI: 10.1016/j. hal.2011.03.003

Van Aller, R.T. (1985). The Chemistry of Allelopathy. Washington: American Chemical Society, 337-386.

Van Alstyne, K.L., Wolfe, G.V., Freidenburg, T.L., Neill, A., Hicken, C. (2001). Activated defense systems in marine macroalgae: evidence for an ecological role for DMSP cleavage. Marine, Ecology Progress Series, 213, 53-65. DOI: 10.3354/meps213053

Van Donk, E., Gulati, R.D. (1995). Transition of a lake to turbid state six years after biomanipulation: mechanisms and pathways. Water Science and Technology, 32, 197-206. DOI: 10.1016/02731223(95)00699-0

Wang, J.Q., Jin, C.L., Zhang, X., Liu, G. (2001). Polyculture of experiment Penaeus chinensis with various biomass of Ulva pertusa. Journal of Fisheries of China, 25, 32-38.

Wium-Andersen, S., Anthoni, U., Houen, G. (1983). Elemental sulphur, a possible allelopathic compound from Ceratophyllum demersum. Phytochemistry, 22, 2613. DOI: 10.1016/0031-9422(83)80178-2

Wium-Andersen, S., Christophersen, C., Houen, G. (1982). Allelopathic effects on phytoplankton by substances isolated from aquatic macrophytes (Charales). Oikos, 39, 187-190. DOI: 10.2307/3544484

Abstract

Allelopathy is a prevalent natural phenomenon in aquatic ecosystems. We reported the effects of the green macroalga Ulva intestinalis L. collected from estuaries of the Baltic Sea (Poland) on the growth and chlorophyll fluorescence of common filamentous cyanobacterium Nostoc sp. It was found that the addition of 50 $\mu \mathrm{L} \mathrm{mL} L^{-1}$ extracts obtained from U. intestinalis inhibited the growth of cyanobacterium, and, after one week of exposition, the reduction was 35\% of initial amount of Nostoc sp. In addition, we demonstrated that, on the seventh day of the exposition, the values of $\mathrm{F}_{\mathrm{v}} / \mathrm{F}_{\mathrm{m}}$ of target cyanobacterium after the addition of $100 \mu \mathrm{L}$ $\mathrm{mL}^{-1}$ extracts obtained from $U$. intestinalis was reduced to $49 \%$, compared to control treatment. These results showed for the first time the allelopathic activity of $U$. intestinalis on Baltic filamentous cyanobacteria Nostoc sp.

Key words: allelopathy, Chlorophyta, cyanobacteria, extract, fluorescence, green algae, growth, macroalgae, Ulvophyceae

Received: [2018.03.04]

Accepted: [2018.10.30]

\section{Zjawisko oddziaływania allelopatycznego Ulva intestinalis L. na bałtycką sinicę nitkowatą Nostoc sp. \\ Streszczenie}

Allelopatia jest powszechnym zjawiskiem występującym w ekosystemach wodnych. W artykule opisano wpływ zielenicy bentosowej Ulva intestinalis L. (ulwa kiszkowata), zebranej z Morza Bałtyckiego (Zatoka Gdańska); na wzrost i fluorescencję chlorofilu u nitkowatej sinicy Nostoc sp. Na podstawie uzyskanych 
wyników badań stwierdzono, że po dodaniu ekstraktów uzyskanych z U. intestinalis, najmniejszy wzrost Nostoc sp. obserwowano w siódmym dniu eksperymentu. Dodanie $50 \mu \mathrm{L} \mathrm{mL}^{-1}$ ekstraktu z U. intestinalis zahamowało rozwój sinicy Nostoc sp. i po 7 dniu ekspozycji jej wzrost osiągnął poziom 35\% w stosunku do warunków kontrolnych. Ponadto największy spadek wartości parametru fluorescencji $\mathrm{F}_{\mathrm{v}} / \mathrm{F}_{\mathrm{m}}$ dla Nostoc sp. obserwowano po tygodniu trwania eksperymentu. Stwierdzono, że po 7 dniach ekspozycji wartość $\mathrm{F}_{\mathrm{v}} / \mathrm{F}_{\mathrm{m}}$ dla badanej sinicy po dodaniu $100 \mu \mathrm{L} \mathrm{mL} \mathrm{m}^{-1}$ ekstraktu z U. intestinalis spadła o $49 \%$. Przeprowadzone badania po raz pierwszy wykazały, że $U$. intestinalis wpływa allelopatycznie na bałtyckie sinice nitkowate $\mathrm{z}$ rodzaju Nostoc.

Słowa kluczowe: allelopatia, Chlorophyta, ekstrakt, fluorescencja, makroglony, sinice, Ulvophyceae, wzrost, zielenice

\section{Information on the authors}

\section{Gracjana Budzałek}

The field of her interest is allelopathic interactions between macroalgae and cyanobacteria. In her research, she is focusing mostly on Baltic species. She is investigating the influence of allelopathic compounds produced by macroalgae on bloom-forming cyanobacteria.

Sylwia Śliwińska-Wilczewska https://orcid.org/0000-0002-3147-6605

She is interested in the allelopathy of cyanobacteria and microalgae, in particular, of picocyanobacteria Synechococcus sp. Allelopathy plays an important role in interspecific competition and contributes to cyanobacterial bloom maintenance. In her study, the influence of allelochemicals on the growth, chlorophyll fluorescence, and photosynthesis irradiance curves of different phytoplankton species was investigated. She is also investigating the influences of environmental factors on produced allelopathic compounds on algae and cyanobacteria.

Adam Latała https://orcid.org/0000-0001-6092-887X

He has wide experience in ecophysiology and ecotoxicology of marine benthic and planktonic algae, and the influence of the main environmental factors, such as salinity, temperature, and light on the photosynthesis, photoacclimation, fluorescence, respiration, and the growth of algae from natural communities and cultured under laboratory conditions. He studies the use of fluorescence techniques to determine algal and cyanobacterial ecophysiology and ecotoxicology. He is the Curator of Culture Collection of Baltic Algae (CCBA) at the Institute of Oceanography, University of Gdańsk. Actually, CCBA maintains more than 100 Baltic strains from three taxonomic groups: blue-green algae, green algae, and diatoms. 